\title{
ANALISA LAPORAN KEUANGAN BERDASARKAN TINGKAT RENTABILITAS PADA PT. BANK PEMBANGUNAN DAERAH SUMATERA BARAT
}

\author{
Zea Putri Yonanda ${ }^{1)}$, Jhon Fernos ${ }^{2)}$ \\ 1.2) Akademi Keuangan dan Perbankan "Pembangunan" Padang \\ zeaputri2704@gmail.com
}

\begin{abstract}
The purpose of this study is to determine the analysis of financial statements based on the level rentabilitas at PT. Bank Pembangunan Daerah Sumatera Barat. Data analysis method using quantitative data, namely data sourced from the financial statements of PT. Bank Pembangunan Daerah Sumatera Barat. Based on the results of research where the 2017-2019 perio shows that, the average NPM value $24.42 \%$, with the standards set by Bank Indonesia $3 \%-12.5 \%$, the evaluation results are very good. For an average ROA value $1.47 \%$, with the standards set by Bank Indonesia of $0.5 \%-1.25 \%$, the evaluation results are good. For an average ROE value 21\%, with the standard set by Bank Indonesia of $5 \%-12.5 \%$, the evaluation results are very good.
\end{abstract}

Keywords: Financial statements, Rentabilitas, NPM, ROA, ROE.

\section{PENDAHULUAN}

Pada masa saat ini peran bank sangat penting dalam kehidupan masyarakat, dimana pada dasarnya perbankan bertujuan untuk menunjang pembangunan nasional dalam meningkatkan keamanan masyarakat. Dimana pada saat ini perbankan mengalami perkembangan yang sangat pesat, baik Bank Umum ataupun Bank Perkreditan Rakyat, untuk itu bank diharapkan mampu menjaga rentabilitas suatu bank tersebut.

(Undang-Undang No.10 Tahun 1998 tentang perubahan undang-undang No. 7 Tahun1992, 1998) Bank merupakan kegiatan yang mengumpulkan dana dalam bentuk tabungan dan kemudian menyalurkan kembali dalam bentuk kredit untuk meningkatkan taraf seluruh masyarakat.

Laporan keuangan merupakan data-data keuangannya yang sifatnya kauntitatif, dan berisikan awal informasi yang signifikan akan memahami dan menganalisis keadaan keuangan suatu bank. Menurut (Dwimulyani \& Shirley, 2018) dalam bukunya Financial Statement Analisis menyatakan bahwa yang dimaksud dengan laporan keuangan ialah catatan yang disesuaikan oleh yang betugas menyususun, mengawasi data laporan pada akhir tahun untuk suatu perusahaan. Kedua catatan itu berisi tentang nerca atau posisi keuangan pendapatan atau laba rugi. Sekarang sudah menjadi kepandaian bagi perusahaan untuk memberikan catatan ketiga yaitu surplus atau laba yang dibagikan (laba yang ditahan).

Posisi keuangan mempunyai misi yang ingin dicapai perusahaan yaitu mencapai laba yang maksimal sebab manajemen perusahaan dalam kegiatan dituntut mampu menggapai target yang telah ditetapkan. Jadi besar keuntungan harus sesuai dengan target tidak hanya mengharapkan untung. Untuk 
memperkirakan tinkat laba perusahaan, maka digunakan rasio keuntungan yang dikenal dengan nama rasio Rentabilitas.

Menurut (Winda Parascintya Bukian \& Merta Sudiartha, 2016) menyebutkan bahwa rentabilitas ialah membuktikan keahlian perushaan dalam meningkatkan keuntungan atau laba dalam periode tertentu. Rasio pada perusahaan ini dapat dilihat dengan membandingakan antara keuntungan (laba) yang diperoleh pada waktu tertentu dengan jumlah aset perusahaan tersebut. Sedangkan menurut (Munawir, 2010) bahwa rentabilitas ialah kepiawaian perusahaan dalam memperoleh laba selama waktu tertentu. Jadi berbagai pendapat diatas dapat disimpulkan bahwa rentabiliatas adalah rasio antara laba dengan modal yang mengdapatkan laba.

Pada PT. Bank Pembangunan Daerah Sumatera Barat tingkat rentabilitas masalah ialah mengukur suatu efesieni penerapan modal suatu perusahaan dengan membandingkan antara (laba) dengan modal yang digunakan dalam operasi. Sebab keuntungan yang besar tidakmenjamin ukuran bahwa perusahaan tersebut Reliabel.

Data mengenai perkembangan laporan keuangan PT. Bank Pembangunan Daerah Sumatera Barat bisa memperhatiakn tabel berikut:

\section{Tabel 1}

Data Perkembangan Rasio Rentabilitas

PT. Bank Pembangunan Daerah Sumatera Barat

Periode 2017-2019

(dalam Rp. 000)

\begin{tabular}{cccc}
\hline Tahun & Net Profit Margin & Return On Aset & $\begin{array}{c}\text { Return On } \\
\text { Equity }\end{array}$ \\
\hline 2017 & $23,80 \%$ & $1,40 \%$ & $19,45 \%$ \\
2018 & $23,69 \%$ & $1,48 \%$ & $21,18 \%$ \\
2019 & $25,79 \%$ & $1,54 \%$ & $22,38 \%$ \\
\hline
\end{tabular}

Sumber: PT. Bank Pembangunan daerah Sumatera Barat, data diolah

Dari data diatas menunjukan bahwa pada tahun 2017 NPM PT. Bank pembangunan Daerah Sumatera Barat 23,80\%, tahun 2018 23,69\%, tahun 2019 $25,79 \%$ yang diperoleh dari laba bersih setelah pajak dibagi dengan pendapatan operasioanal. Sedangkan untuk ROA tahun 2017 1,40\%, tahun 2018 1,48\%, dan pada tahun 2019 1,54\% yang diperoleh dari laba bersih setelah pajak dibagi dengan total aset, dan untuk ROE tahun 2017 19,54\%,tahun 2018 21,18\%, dan pada tahun 2019 22,38\% yang diperoleh dari laba bersih setelah pajak dibagi dengan modal sendiri.

Dari uraian diatas, penulis ingin mengetahui bagaimana kepiawaian PT.Bank Pembangunan Daerah Sumatera Barat dalam menggunakan modalnya secara efisien serta menggunakan aktivanya bergunan untuk meningkatkan laba semasa waktu tertentu dengan tujuan perusahaan tersebut dapat mengoperasikan secara stabil dan mampu mengembalikan semua hutang-hutangnya kepada pihak lain. 


\section{METODE PENELITIAN \\ Metode Pengumpulan Data}

Untuk keperluan penelitian ini, pengumpulan data dilakukan dengan dua cara yaitu: a.studi lapangan (Field Research) yaitu penulis langsung turn kelapangan untuk melengkapi data yang diperlukan. Penelitian dilapangan dapat melakukan dengan mewawancarai bagan pihak yang berkepentingan sesuai dengan instansi yang terkait. b, studi perpustakaan( Library Research) yaitu penelitian ini dilakukan kepustaka dengan mencari informasi melalui buku-buku ilmiah dan tulisan-tulisan yang berhubungan dengan pembahasan yang dilakukan.

\section{Metode Analisa Data}

Pada analisis data, penulis menggunakan data kuantitatif sebagai metode penelitian, dimana metode kuantitatif tersebut kegiatannya adalah data yang bersumber dari laporan keuangan berupa angka-angka. Dalam metode ini penulis menjelaskan data secara fakta yang dialami sesuai dengan teori yang ada. Analisis ini digunakan untuk mengukur tingkat rentabilitas Dalam menganalisa data, penulis menggunakan analisis Net Profit Margin (NPM), Return On Assets (ROA) dan Return On Equity ( ROE)

\section{HASIL DAN PEMBAHASAN}

\section{Pengertian Analisis laporan keuangan}

Merupakan proses dalam penilaian dalam rangka membantu memeriksa pos keuangan dan hasil perusahaan pada masa saat ini maupun masa lampau, dengan arah menentukan penilaian dan perkiraan mengenai keadaan dan kinerja perusahaan pada masa akan datang. Agar laporan keuangan dipahami oleh semua kalangan, analisa dapat dilakukan dengan jeli dan teliti dengan cara proses analisa yang tepat. Setelah laporan keuangan ditata berdasarkan data yang relevan, serta digunakan dengan moteode akuntansi dan penilaian yan benar, akan tampak keadaan keuangan perusahaan yang sesungguhnya akan diketahui jumlah berapa biaya yang dikeluarkan dalam waktu tertentu. Dengan demikin mampu bagaimana memperoleh hasil usaha (laba/rugi) yang diperoleh selama periode tertentu dari laporan lab rugi yang disediakan.

Analisa laporan keuangan dijelaskan oleh (Recly, 2016) merupakan analisa untuk memastikan pos keuangan dan hasil operasi serta perkembangan usaha yang berkaitan. Analisa laporan keuangan dilakukan dengan cermat menggunakan metode dan teknis analisis yang tepat. Hasil analisi laporan keuangan juga menyampaikan informasi tentang kekurangan dan kelebihan yang dimiliki perusahaan. Melihat kekurangan perusahaan akan menutupi dan memperbaiki kekurangan tersebut. Kemudian kelebihan yang dimiliki perusahaan harus tetap dipertahankan dan ditingkatkan dari yang sebelumnya

\section{Pengertianm Rentabilitas}

Ialah kepandaian perusahaan dalam meningkatkan laba dengan semua dana yang ada didalamnya. Menurut (Setiawan, 2016) rentabilitas merupakan patokan sekitar laba dengan aktiva atau modal yang telah dimiliki perusahaan yang dapat menghasilkan laba. Dengan kata lain rentabilitas ialah kepiawaian suatu perusahaan dalam meningkatkan laba selama periode tertentu. Sedangkan menurut (Rompas, 2016) rasio rentabilitas ialah dimana tujuannya untuk 
memahami kepiawaian bank dalam menghasilkan laba saat periode tertentu, seta mengukur tingkat efesiensi dari usaha keuntungan yang dicapai dalam periode tertentu.

\section{Pengertian Net Profit Margin (NPM)}

Merupakan perbandingan yang dipakai untuk menilai kepiawaian bank dalam mendapatkan (menghasilkan) laba bersih dari aktivitas operasi pokoknya. Atau menghitung sejauh mana kepiawaian bank dalam menghasilkan laba bersih pada tingkat penjualan tertentu. Menurut (Santoso, 2013) adalah menilai besarnya keuntungan yang diperoleh perusahaan dibandingkan dengan pemasarannya. Rumus untuk mencari Net Profit Margin (NPM) sebagai berikut:

$$
\begin{aligned}
& N P M=\frac{\text { Laba Bersih Setelah Pajak }}{\text { Pendapatan Operasional }} \times 100 \% \\
& \text { Pengertian Return On Assets (ROA) }
\end{aligned}
$$

Rasio ini digunakan untuk menentukan kebijakan manajemen bank dalam dalam memperoleh keuntungan (laba). Semakin tinggi Return On Assets (ROA) suatu bank, bertambah pula tinggi tingkat laba yang dicapai bank tersebut dan bertambah baik pula posisi bank tersebut dari segi penggunaan aset (Afriyeni, 2017). Rumus untuk mencari Return On Assets (ROA).

$$
\begin{aligned}
& \text { ROA }=\frac{\text { Laba Bersih Setelah Pajak }}{\text { Total Asset }} \times 100 \% \\
& \text { Pengertian Return On Equity (ROE) }
\end{aligned}
$$

\section{Pengertian Return On Equity (ROE)}

Adalah perbandingan dari hasil laba bersih sesudah pajak dengan total modal yang dimiliki perusahaan. Menurut (Kamal, 2016) Return On Equity (ROE) adalah perbandingan dalam meghitung keeuntungan bersih setelah pajak dengan modal sendiri. Semakin tinggi Return On Equity maka semakin bagus. Artinya posisi milik perusahaan semakin kuat. Rumus mencari Return On Equity sebagai berikut:

$$
R O E=\frac{\text { Laba Bersih Setelah Pajak }}{\text { Modal Sendiri }} \times 100
$$

\section{PEMBAHASAN}

Net Profit Margin (NPM)

\section{Tabel 2}

Perkembangan Net Profit Margin (NPM)

PT. Bank Pembangunan Daerah Sumatera Barat Tahun 2017-2019

(dalam Rp. 000,-)

\begin{tabular}{crrr}
\hline Keterangan & $\mathbf{2 0 1 7}$ & $\mathbf{2 0 1 8}$ & \multicolumn{1}{c}{$\mathbf{2 0 1 9}$} \\
\hline Pendapatan Operasional & 1.264 .951 .718 & 1.453 .162 .781 & 1.462 .095 .179 \\
Laba Bersih Setelah Pajak & 301.124 .236 & 344.323 .016 & 377.106 .552 \\
\hline
\end{tabular}

Sumber : PT. Bank Pembangunan Daerah Sumatera Barat, data olahan 
Dari tabel 2 diatas dapat disimpulkan bahwa Net Profit Margin (NPM) Bank Nagari Sumatera Barat sebagai berikut :

Tahun 2017 :

$$
\begin{aligned}
\text { NPM } & =\frac{\text { Laba Bersih Setelah Pajak }}{\text { Pendapatan Operasional }} \times 100 \% \\
& =\frac{\operatorname{Rp~} 301.124 .236}{\operatorname{Rp} 1.264 .951 .718} \times 100 \% \\
& =23.81 \%
\end{aligned}
$$

Tahun 2018 :

$$
\begin{aligned}
\text { NPM } & =\frac{\text { Laba Bersih Setelah Pajak }}{\text { Pendapatan Operasional }} \times 100 \% \\
& =\frac{\operatorname{Rp~} 344.323 .016}{\operatorname{Rp~} 1.453 .162 .781} \times 100 \% \\
& =23,69 \%
\end{aligned}
$$

\section{Tahun 2019 :}

$$
\begin{aligned}
\text { NPM } & =\frac{\text { Laba Bersih Setelah Pajak }}{\text { Pendapatan Operasional }} \times 100 \% \\
& =\frac{\text { Rp } 377.106 .552}{\operatorname{Rp} 1.462 .095 .179} \times 100 \% \\
& =25,79 \%
\end{aligned}
$$

Tabel 3

Perhitungan Net Profit Margin (NPM)

PT. Bank Pembangunan Daerah Sumatera Barat

Tahun 2017-2019

(dalam Rp. 000,-)

\begin{tabular}{cccc}
\hline Tahun & $\begin{array}{c}\text { Laba Bersih Setelah Pajak } \\
(\mathbf{1})\end{array}$ & $\begin{array}{c}\text { Pendapatan Operional } \\
(\mathbf{2})\end{array}$ & $\begin{array}{c}\text { Net Profit Margin } \\
(\mathbf{1 : 2} \mathbf{1 0 0 \%})\end{array}$ \\
\hline 2017 & 301.124 .236 & 1.264 .951 .718 & $23,80 \%$ \\
2018 & 344.323 .016 & 1.453 .162 .718 & $23,69 \%$ \\
2019 & 377.106 .552 & 1.462 .095 .179 & $25,79 \%$ \\
\hline
\end{tabular}

Sumber: Bank Nagari Sumatera Barat, data olahan

Dari tabel 3 diatas dapat dilihat laba bersih setelah pajak pada tahun 2017 sebanyak Rp. 301.124.236.000,- dengan pendapatan operasional sebanyak Rp. 1.264.951.718.000,- dengan Net Profit Margin (NPM) sebesar 23,81 \% dan pada tahun 2018 laba bersih setelah pajak Rp. 344.323.016.000,- dengan pendapatan 
operasional Rp. 1.453.162.781.000,- dengan Net Profit Margin (NPM) sebesar 23,69\% terjadi penurunan dari tahun sebelumnya. Sedangkan pada tahun 2019 agak terjadi peningkatan dari tahun sebelumnya dengan laba bersih setelah pajak Rp. 377.106.552.000,- dengan pendapatan operasional Rp. 1.462.095.179.000,dengan Net Profit Margin (NPM) sebesar 25,79\% terjadi peningkatan dari tahun sebelumnya.

Return On Assets (ROA)

Tabel 4

Perkembangan Return On Assets (ROA)

PT. Bank Pembangunan Daerah Sumatera Barat

Tahun 2017-2019

(dalam Rp. 000,-)

\begin{tabular}{lrrr}
\hline \multicolumn{1}{c}{ Keterangan } & \multicolumn{1}{c}{$\mathbf{2 0 1 7}$} & \multicolumn{1}{c}{$\mathbf{2 0 1 8}$} & \multicolumn{1}{c}{$\mathbf{2 0 1 9}$} \\
\hline Total Asset & 21.371 .463 .636 & 23.190 .691 .425 & 24.433 .595 .767 \\
Laba Bersih Setelah Pajak & 301.124 .236 & 344.323 .016 & 377.106 .552 \\
\hline
\end{tabular}

Sumber: Bank Pembangunan daerah Sumatera Barat, data olahan

Dari tabel 4 diatas dapat disimpulkan bahwa Return On Assets (ROA) PT. Bank Pembangunan Daerah Sumatera Barat sebagai berikut :

Tahun 2017 :

$$
\begin{aligned}
\text { ROA } & =\frac{\text { Laba Bersih Setelah Pajak }}{\text { Total Aset }} x 100 \% \\
& =\frac{\operatorname{Rp~} 301.124 .236}{\operatorname{Rp~21.371.463.636}} \times 100 \% \\
& =1,40 \%
\end{aligned}
$$

Tahun 2018 :

$$
\begin{aligned}
\text { ROA } & =\frac{\text { Laba Bersih Setelah Pajak }}{\text { Total Aset }} \times 100 \% \\
& =\frac{\text { Rp344.323.016 }}{\operatorname{Rp} 23.190 .691 .425} \times 100 \\
& =1,48 \%
\end{aligned}
$$

Tahun 2019 :

$$
\mathrm{ROA}=\frac{\text { Laba Bersih Setelah Pajak }}{\text { Total Aset }} \times 100 \%
$$




$$
\begin{aligned}
& =\frac{\operatorname{Rp} 377.619 .953}{\operatorname{Rp} 24.433 .595 .767} x 100 \\
& =1,54 \%
\end{aligned}
$$

\section{Tabel 5}

Perhitungan Return On Assets (ROA)

PT. Bank Pembangunan Daerah Sumatera Barat

Tahun 2017-2019

(dalam Rp. 000,-)

\begin{tabular}{lrcc}
\hline Tahun & $\begin{array}{c}\text { Laba Bersih setelah pajak } \\
(\mathbf{1})\end{array}$ & $\begin{array}{c}\text { Total Asset } \\
(\mathbf{2})\end{array}$ & $\begin{array}{c}\text { Return On Assets } \\
(\mathbf{1 : 2 x} 100 \%)\end{array}$ \\
\hline 2017 & 301.124 .236 & 21.371 .463 .636 & $1,40 \%$ \\
2018 & 344.323 .016 & 23.190 .691 .425 & $1,48 \%$ \\
2019 & 377.619 .953 & 24.433 .595 .767 & $1,54 \%$ \\
\hline
\end{tabular}

Sumber:PT. Bank Pembangunan Daerah Sumatera Barat, data olahan

Dari tabel 5 diatas dapat dilihat laba bersih setelah pajak pada tahun 2017 sebanyak Rp. 301.124.236.000,- dengan total aset sebanyak Rp. 21.371.463.362.000,- dengan Return On Assets (ROA) sebesar 1,40\% dan pada tahun 2018 laba bersih setelah pajak Rp. 344.323.016.000,- dan Total aset sebesar Rp. 23.190.691.425.000,- dengan Return On Assets (ROA) sebesar 1,48\%\% terjadi kenaikan dari tahun sebelumnya. Sedangkan pada tahun 2019 agak terjadi peningkatan dari tahun sebelumnya dengan laba bersih setelah pajak Rp. 377.106.552.000,- dan Total Aset sebesar Rp. 24.433.595.767.000,- dengan Return On Assets (ROA) sebesar $1,54 \%$ terjadi peningkatan dari tahun sebelumnya.

\begin{tabular}{|c|c|c|c|}
\hline $\begin{array}{r}\text { Perkem } \\
\text { PT. Bank P }\end{array}$ & $\begin{array}{c}\text { Tabel } 6 \\
\text { ngan Return } O \\
\text { bangunan Daes } \\
\text { Tahun 2017-2 } \\
\text { ( dalam Rp. 00 }\end{array}$ & $\begin{array}{l}\text { Equity (ROE) } \\
\text { h Sumatera Ba } \\
\text { (9) } \\
- \text { ) }\end{array}$ & \\
\hline rangan & 2017 & 2018 & 2019 \\
\hline diri & 1.547 .985 .000 & 1.625 .285 .000 & 1.687 .697 .000 \\
\hline h Setelah Pajak & 301.124 .236 & 344.323 .016 & 377.106 .552 \\
\hline
\end{tabular}

Return on Equity (ROE)

Dari tabel 6 diatas dapat disimpulkan bahwa Return On Equity (ROE) PT. Bank Pembangunan Daerah Sumatera Barat sebagai berikut :

Tahun 2017 :

$$
\mathrm{ROE}=\frac{\text { Laba Bersih Setelah Pajak }}{\text { Modal Sendiri }} x 100
$$




$$
\begin{aligned}
& =\frac{\mathrm{Rp} 301.124 .236}{\mathrm{Rp} 1.547 .985 .000} \times 100 \% \\
& =19.45 \%
\end{aligned}
$$

\section{Tahun 2018 :}

$$
\begin{aligned}
\text { ROE } & =\frac{\text { Laba Bersih Seteah Pajak }}{\text { Modal Sendiri }} \times 100 \% \\
& =\frac{\operatorname{Rp~} 344.323 .016}{\operatorname{Rp~} 1.625 .285 .000} \times 100 \% \\
& =21,18 \%
\end{aligned}
$$

Tahun 2019:

$$
\begin{aligned}
\text { ROE } & =\frac{\text { Laba Bersih Setelah Pajak }}{\text { Modal Sendiri }} \times 100 \% \\
& =\frac{\text { Rp } 377.619 .953}{\operatorname{Rp~} 1.687 .697 .000} \times 100 \% \\
& =22,37 \%
\end{aligned}
$$

Tabel 7

Perhitungan Return On Equity (ROE)

PT. Bank Pembangunan Daerah Sumatera Barat

Tahun 2017-2019

(dalam Rp. 000,-)

\begin{tabular}{lrcc}
\hline Tahun & $\begin{array}{c}\text { Laba Bersih Setelah Pajak } \\
\text { (1) }\end{array}$ & $\begin{array}{c}\text { Modal Sendiri } \\
(\mathbf{2})\end{array}$ & $\begin{array}{c}\text { Return On Equity } \\
(\mathbf{1 : 2 x} 100 \%)\end{array}$ \\
\hline 2017 & 301.124 .236 & 1.547 .985 .000 & $19,45 \%$ \\
2018 & 344.323 .016 & 1.625 .285 .000 & $21,18 \%$ \\
2020 & 377.619 .953 & 1.687 .697 .000 & $22,37 \%$ \\
\hline
\end{tabular}

Sumber : PT. Bank Pembangunan Daerah Sumatera Barat, data olahan

Dari tabel 7 diatas dapat dilihat laba bersih setelah pajak pada tahun 2017 sebanyak Rp. 301.124.236.000,- dan modal sendiri adalah sebesar Rp. 1.547.985.000..000,- dengan Return On Equity (ROE) sebesar 19,45\% dan pada tahun 2018 laba bersih setelah pajak Rp. 344.323.016.000,- dan Modal sendiri sebesar Rp. 1.625.285.000.000,- dengan Return On Equity (ROE) sebesar $21,18 \% \%$ terjadi kenaikan dari tahun sebelumnya. Sedangkan pada tahun 2019 agak terjadi peningkatan dari tahun sebelumnya dengan laba bersih setelah pajak Rp. 377.106.552.000,- dan modal sendiri sebesar Rp. 1.687.697.000.000,dengan Return On Equity (ROE) sebesar 22,37\% terjadi peningkatan dari tahun sebelumnya . Jika dilihat dari persentase diatas maka disimpulkan bahwa PT. Bank Pembangunan Daerah Sumatera Barat mendapatkan laba maksimal dari odal sendiri yang dimiliki. 
Berdasarkan analisa diatas, maka untuk masing-masing kelompok rasio diatas, maka dapat disimpulkan rasio-rasio tersebut berdasarkan Rata-rata Industri sebagai berikut:

\section{Tabel 8 \\ Perkembangan NPM, ROA, ROE \\ PT. Bank Pembangunan Daerah Sumatera Barat \\ Berdasarkan standar Bank Indonesisa No 6/10/PBI/2004 \\ Tahun 2017 - 2019}

\begin{tabular}{|c|c|c|c|c|c|c|c|}
\hline Rasio & Standar BI & $\begin{array}{c}\text { Tahun } \\
2017\end{array}$ & Evaluasi & $\begin{array}{c}\text { Tahun } \\
2018\end{array}$ & Evaluasi & $\begin{array}{c}\text { Tahun } \\
2019\end{array}$ & Evaluasi \\
\hline NPM & $3 \%-12,5 \%$ & $23,80 \%$ & $\begin{array}{c}\text { Sangat } \\
\text { Baik }\end{array}$ & $23,69 \%$ & $\begin{array}{c}\text { Sangat } \\
\text { Baik }\end{array}$ & $25,79 \%$ & $\begin{array}{c}\text { Sangat } \\
\text { Baik }\end{array}$ \\
\hline ROA & $0,5 \%-1,25 \%$ & $1,40 \%$ & Baik & $1,48 \%$ & Baik & $1,54 \%$ & Baik \\
\hline ROE & $5 \%-12,5 \%$ & $19,45 \%$ & $\begin{array}{l}\text { Sangat } \\
\text { Baik }\end{array}$ & $21,18 \%$ & $\begin{array}{c}\text { Sangat } \\
\text { Baik }\end{array}$ & $22,37 \%$ & $\begin{array}{l}\text { Sangat } \\
\text { Baik }\end{array}$ \\
\hline
\end{tabular}

Sumber: Hasil Evaluasi Rasio dari Standar BI

Hasil evaluasi rasio rata-rata industri pada PT. Bank Pembangunan Daerah Sumatera Barat, maka dapat diuraikan sebagai berikut:

a. Net Profit Margin (NPM) pada PT. Bank pembangunan Daerah Sumatera Barat dengan nilai NPM 24,42\% > 3\% - $12,5 \%$ yang ditetapkan standar Bank Indonesia No 6/10/PBI/2004 dengan hasil evaluasi sangat baik artinya perusahaan dengan pendapatan operasional mampu menghasilkan laba setelah pajak

b. Return On Asset (ROA) pada PT. Bank pembangunan Daerah dengan nilai ROA $1,47 \%>0,5 \%-1,25 \%$ yang ditetapkan Standar Bank Indonesia No 6/10/PBI/2004 dengan hasil evaluasi baik artinya perusahaan bisa menggunakan atau memanfaatkan aktiva yang dimilikinya di dalam menghasilkan laba setelah pajak.

c. Return On Equity (ROE) pada PT. Bank Pembangunan Daerah Sumatera Barat dengan nilai ROE $21 \%>5 \%-12,5 \%$ yang ditetapkan Standar Bank Indonesia No 6/10/PBI/2004 artinya perusahaan dalam menghasilkan laba dengan modal sendiri yang berasal dari pemilik, perusahaan ini mampu menghasilkan tingkat keuntungan/laba.

\section{SIMPULAN}

Berdasarkan analisis diatas terhadap laporan keuangan PT. Bank Pembangunan Daerah Sumatera barat maka peneliti menarik kesimpulan dimana standar Bank Indonesia No 6/10/PBI/2004 untuk Net Profit Margin (NPM) yang ditetapakan oleh bank Indonesia sebesar 3\% - 12,5\% dan Return On Asset (ROA) 0,5\% - 1,25\% serta Return ON Equity (ROE) 5\% - 12,5\%. Net Profit Margin (NPM) pada PT. Bank Pembangunan Daerah Sumatera Barat dengan nilai NPM 24,42\% > standar Bank Indonesia dengan hasil evaluasi sangat baik artinya perusahaan dengan pendapatan operasional mampu menghasilkan laba setelah pajak sedangkan Return On Asset (ROA) PT. Bank Pembangunan Daerah Sumatera barat dengan nilai ROA 1,47\% > 
standar Bank Indonesia dengan hasil evaluasi baik artinya perusahaan dapat menggunakan atau memanfaatkan aktiva yang dimilikinya didalam menghasilkan laba setelah pajak. Untuk Return On Equity (ROE ) pada PT. Bank Pembangunan Daerah Sumatera barat dengan nilai ROE 21\% > standar Bank Indonesia artinya perusahaan dalam menghasilkan laba dengan modal sendiri yang berasal dari pemilik, perusahaan ini mampu menghasilkan tingkat keuntungan/laba

\section{UCAPAN TERIMA KASIH}

Penulis mengucapkan terima kasih kepada PT. Bank Pembangunan Daerah Sumatera Barat yang telah mengizinkan dan membantu penulis dalam memperoleh informasi. Serta semua pihak yang telah membantu penulis dalam penyelesaian artikel ini.

\section{DAFTAR PUSTAKA}

Afriyeni, A. (2017). Profitabilitas Bank Perkreditan Rakyat Di Kota Padang Di Tinjau Dari Rasio Likuiditas. Jurnal Benefita, 2(1), 22-32.

Arifin, I. Z., \& Marlius, D. (2017). Analisis Kinerja Keuangan PT. Pegadaian Cabang Ulak Karang. https://doi.org/10.31227/osf.io/n2peu

Dwimulyani, S., \& Shirley, S. (2018). Analisis Pengaruh Pertumbuhan RasioRasio Keuangan, Laba Bersih, Dan Ukuran Perusahaan Terhadap Prediksi Pertumbuhan Laba Usaha Pada Perusahaan Manufaktur Yang Terdaftar Di Bej. Jurnal Informasi, Perpajakan, Akuntansi, Dan Keuangan Publik, 2(1), 43. https://doi.org/10.25105/jipak.v2i1.4426

Handayani, M., \& Marlius, D. (2017). Analisis Tingkat Kesehatan PT. BPR Batang Kapas. https://doi.org/10.31227/osf.io/bq48z

Kamal, M. B. (2016). Pengaruh Receivable Turn Over Dan Debt To Asset Ratio (DAR) Pada Perusahaan Pertanian Yang Terdaftar Di Bursa Effek. Jurnal Ilmiah Manajemen Dan Bisnis, 17(02), 68-81. http://jurnal.umsu.ac.id

Marlius, D., \& Sukma, J. (2020). Analisis Tingkat Kesehatan Bank Pt. Bank Perkreditan Rakyat Jorong Kampung Tangah Pariaman Cabang Padang. https://doi.org/10.31219/osf.io/dmjy5

Munawir, S. (2010). Analisa Laporan Keuangan Edisi 4. Yogyakarta: Liberty.

Mustika, S., \& Marlius, D. (2019). Analisa Tingkat Kesehatan Keuangan PT. Bank Perkreditan Rakyat (BPR) Batang Palangki. https://doi.org/10.31219/osf.io/wupyh

Putri, Y. A., \& Marlius, D. (2018). Analisis Tingkat Kesehatan Bank Pada PT. Bank Perkreditan Rakyat (BPR) Jorong Kampuang Tangah Pariaman Cabang Padang. https://doi.org/10.31227/osf.io/r98pv

Rahmayeli, D. S., \& Marlius, D. (2017). Analisis Kinerja Keuangan Pada PT. Bank Perkreditan Rakyat (BPR) Batang Kapas Pesisir Selatan. https://doi.org/10.31227/osf.io/sz5db

Recly, R. B. (2016). Analisis Rasio Keuangan Untuk Menilain Kinerja Keuangan Pada Pt. H . M Sampoerna Tbk Triyonowati Sekolah Tinggi Ilmu Ekonomi Indonesia ( Stiesia) Surabaya. 5. 
Rompas, G. P. (2016). Likuiditas, Solvabilitas dan Rentabilitas Terhadap Nilai Perusahaan BUMN Yang Terdaftar Di BEI. Jurnal EMBA, 1(3), 252-262.

Santoso, C. (2013). Perputaran Modal Kerja Dan Perputaran Piutang Pengaruhnya Terhadap Profitabilitas Pada Pt. Pegadaian (Persero). Jurnal Riset Ekonomi, Manajemen, Bisnis Dan Akuntansi, 1(4), 1581-1590.

Setiawan, I. (2016). Pengaruh Modal Kerja terhadap Rentabilitas pada PT. Ades Waters Indonesia Tbk. Jakarta Selama Periode 2002-2009. Jurnal Ilmiah AKuntansi Universitas Pamulang, 4(1), 942-957. http://openjournal.unpam.ac.id/index.php/JIA/article/view/152

Undang-Undang No.10 Tahun 1998 tentang perubahan undang-undang No. 7 Tahun1992. (1998). Undang-Undang Republik Indonesia No. 10 Tahun 1998 Tentang Perbankan. Lembaran Negara Republik Indonesia, 182.

Winda Parascintya Bukian, N., \& Merta Sudiartha, G. (2016). Pengaruh Kualitas Aset, Likuiditas, Rentabilitas Dan Efisiensi Operasional Terhadap Rasio Kecukupan Modal. E-Jurnal Manajemen Universitas Udayana, 5(2), 255028. 